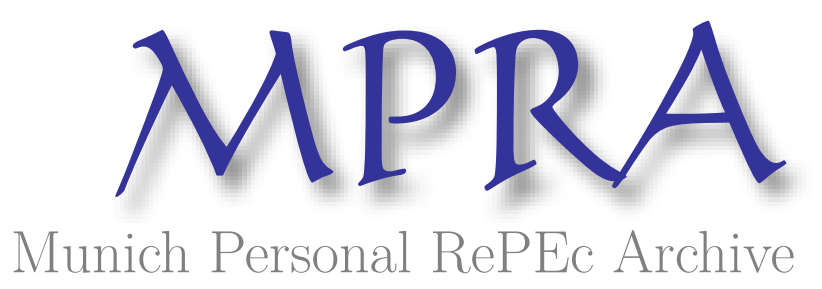

Commodity Prices and Macroeconomic
Variables in India: An Auto-Regressive
Distributed Lag (ARDL) Approach

Jena, Pratap Kumar

North Orissa University

2015

Online at https://mpra.ub.uni-muenchen.de/73892/

MPRA Paper No. 73892, posted 06 Jan 2017 12:50 UTC 


\title{
Commodity Prices and Macroeconomic Variables in India: An Auto-Regressive Distributed Lag (ARDL) Approach
}

\author{
Pratap Kumar Jena \\ Assistant Professor, Department of Economics, North Orissa University, Baripada, \\ Odisha- 757003, India;
}

\begin{abstract}
This paper examines the relationship between commodities index prices and macroeconomic variables in India over the period of January 2001 to June 2012 using the time series techniques of ARDL model and ECM model. The ARDL test suggests that there is longrun cointegration between agriculture index price and macroeconomic variables, and also between energy index price and macroeconomic variables. But, there is no long-run cointegration between metal index price and macroeconomic variables. The results also indicate that IIP and Exchange rate have positive and significant effects on the agricultural index price. This implies that that IIP and Exchange rate are vital macroeconomic variables that influence the agricultural index price in the study period. Similarly, the aggregate demand (i.e. IIP) is the positive and significant effect on energy index price. This implies that that IIP is a vital macroeconomic variable that influences the energy index price in the study period. But, there is no such macroeconomic variable we found which have a significant effect on the metal index price.
\end{abstract}

Keywords: Commodity Price, Macroeconomic, ARDL, ECM

JEL Classification: E31, E01 ,C51

\section{Introduction:}

In the $21^{\text {st }}$ century, the volatility of commodity prices has taken attention of policy makers and academic researchers to study on commodity markets in world-wide. The recent rose of commodity prices since 2002 to mid of 2008 is exceptional in terms of a number of commodities and duration. Commodities have multiple uses in day to day life and its demand is always greater than the supply. Therefore, the recent rise in commodity prices is not only put a heavy burden on developing and emerging economies like India and also it fuels inflation in the country. There are arguments and debates to understand what are the causes and consequences of the recent rise of commodity prices in India. In the debate and arguments, researchers have given more importance to two factors, which are well connected. Firstly, they gave importance to 
fundamental factors and secondly, they gave importance to the financialization of commodity markets.

The recent raises of commodities prices are due to growing of world income and there is no match between the supply of and demand for commodities (OECD-FAO, 2008). The second fold of argument attributes to the recent rising of financialisation of commodity markets (UNCTAD report, 2009). The strong and sustained increase in primary commodity prices from 2002 to 2008 was attended by the growing financial investors on commodity futures exchanges, as investors use commodity as an alternative investment asset class. The investors are not interested in individual commodity but they are interested in investing on group of commodities like index investment. Since 2003 to mid-2008 there has been continuously increased the total value of various commodity index-related investments estimated $\$ 15$ billion to $\$ 200$ billion (CFTC staff report, 2008).

Commodity prices in the international market have dramatized trends; sometimes there have continuous upward trends and sometimes downward trends. But, commodity prices started rising in a different way since 2002 and it severely hit by the global financial crisis in the mid of 2008. It is observed that the prices of some commodities reached even historic high in nominal and real terms in metals, minerals and crude oil. But, due to the crisis, commodity prices experienced a sharp fall due to global economic uncertainties and financial shocks. It continued to till the global economy recovered from the crisis in 2009. Thereafter, commodity prices started upward trend during the first quarter of 2009 despite the continuation of the global economic downturn.

Basically, agricultural and food commodity prices were severely heated by the financial downturn and long-term declined nearly $50 \%$ in real prices than other commodities. Such price declined led to low income and low economic growth of agricultural producers and developing countries. Another reason for rising commodity prices is the Doha Round of WTO, they reduced the agricultural support and trade barriers for the developed or high-income nations. It led to a rising of commodity prices, income and welfare of the agricultural commodities exporting countries (Aksoy \& Beghin, 2005 and Anderson \& Masters, 2009).

There are many common factors which influence commodity markets. The price dynamics are differing across commodity groups. For example, the global economic recession 
has not affected all sectors in the same way. Some sectors, such as sugar and coffee, are benefited from increased demand, whereas others, such as cotton, has hit hard by the crisis. Similarly, climatic shocks have also differed across agricultural commodity groups (UNCTAD, 2010).

Commodity prices in India were peaked before the mid of 2008 but became low during the depth of the financial crisis. Before mid-2008, energy prices were more than double and it became $\$ 144$ per barrel. Similarly, metals prices were up 150 percent while agricultural prices were 77 or higher (MCX Commodity Year Book, 2011). There was sharp fall of food, metals and energy prices during the financial crisis in world-wide. But in the early of 2009, all commodity prices came to the old track due to stimulus packages and policy actions by the Indian government.

The vast public attention takes place on increase in commodity price volatility but and growth of commodity index investment has gone unnoticed among them. Therefore, the present study investigates to find out the possible macroeconomic factors that help the recent boom of commodity prices in India. Therefore, this paper is organized into following sections. Section-2 deals with literature review. Sample size and data sources are reported in section-3. In section-4, we have reported the methodology of the study. In section-5, we have reported the analysis of estimated results. The last section- 6 gives the conclusion of the study.

\section{Literature Review}

The high volatility of commodity prices in India gives pain to policy makers and researchers to find out the reasons behind it. This leads to difficulty in predicting the commodity prices of essential commodities. Among factors, the macroeconomic factors attract more to the policy makers and researchers. As the macroeconomic factors play the major role in the change in demand and supply. Different economists have suggested different macroeconomic factors which affect commodity prices both in the short-run and in the long-run. Therefore, this paper attempts to find out factors which affect commodity price in India. There are studies like; Dornbusch (1985), Lescaroux (2009), Borensztein and Reinhart (1994), Chambers and Bailey (1996), Labys and Maizels (1990), Frankel and Hardouvelis (1985), Christie-David, et al. (2000), 
Kim et al. (2011), Nag and Goswami (2008), Kabia and Gil (2000), Kaufmann (2011), Palaskas and Varangis (1991), Frankel (2006), Gilbert (1990), Anderson and et al. (2003), Barnhart (1989), Cai, Cheung and Wong (2001), Erb and Harvey (2006) and etc, which show the relationship between macroeconomic factors and commodity prices,

Durnbusch (1984) shows the effects of real exchange rate on commodity price. Lescaroux (2009) examined the excess-comovement of commodity prices- a special reference to how fundamental factors are playing a major role in short-run dynamics. His framework was unable to explain the marked and sustained weakness in commodity prices during the 1980s and 1990s. Borensztein and Reinhart (1994) extended that framework in two directions: first, it incorporates commodity supply in the analysis, capturing the impact on prices of the sharp increase in commodity exports of developing countries during the debt crisis of the 1980s. Second, it takes a broader view of "world" demand that extends beyond the industrial countries and includes output developments in Eastern Europe and the former Soviet Union. The results support these extensions, as both the fit of the model improve substantially and, more important, its ability to forecast increases markedly.

Chambers and Bailey (1996) pointed out that the price fluctuations of storable commodities which are traded in open markets are subject to random shocks to demand, more particularly, to supply. Frankel and Hardouvelis (1985) said the reactions of money supply announcement on prices of nine commodities to assess the degree of market credibility that the Fed has in its commitment to money growth target.

Christie-David, et al. (2000) said that gold and silver responded strongly to the release of capacity utilization. Gold also responds strongly to the release of the CPI but silver responds weakly to the CPI. Gold responds weakly to the release of the Federal deficit. Kim, et al. (2011) Soft and hard commodity prices seem to be strongly affected by the financial factor. The financial factor is also an important source of fluctuations in the oil prices.

Nag and Goswami (2008) said that the short-run expansionary effect of the rising in money supply does not persist in the long run through an equi-proportionate rise in the price of the primary commodity, the nominal exchange rate, and the industrial price level. Kaabia and Gil (2000) said that in the long run agricultural prices are homogeneous. That led to the reaction of input and output prices are of the same magnitude. It is also noticeable that, in the long run, 
changes in agricultural variables have not had a significant impact on fundamental variables. In the short-run, agricultural exports are more sensitive to agricultural prices than to any other fundamental variable.

Kaufmann (2008) said that the demand shock in 2007-2008 was due to an increase of Chinese oil demand, led to a sudden increase in non-OPEC production. But halt in demand in 2008 led to the loss of OPEC spare capacity. These changes were reinforced by speculative expectations, but it was difficult to measure directly.

Palaskas and Varangis (1990) said that a commodity price in nominal terms is strongly affected by consumer price but not the reverse. Frankel (2006) he said that monetary, real interest rate influence commodity price. Gilbert (1989) said that the interaction between dollar appreciation and dollar-denominated debt was responsible for the recent low real level of primary commodity prices.

Palaskas and Varangis (1990) rejected the hypothesis of a long-run relationship between real commodity prices and either consumer prices or the money supply. They said that commodity prices in nominal terms (except for metals and minerals) strongly influence consumer price and no inverse relation. This test also shows that the change in money supply causes changes in commodity prices, but commodity prices do not affect the money supply.

Barnhart (1989) finds that monetary variables cause the majority of the significant commodity prices response.

There are studies like Fleming and Remolona (1999), Andersen et al. (2003) which examined the impact of fundamental variables like inflation, money supply, interest rate, etc. in stock markets, bond markets, and foreign exchange markets. But very fewer numbers of studies are available which have examined the impact of fundamental factors on individual commodity. Some of such studies include Barnhart (1989), Christie et al. (2000) and Cai et al. (2001). The dotcom crisis in 2000 has increased the importance of alternative asset investment. It believed that commodity futures are safe and best alternative asset. Therefore, there has been an increased commodity futures trading world-wide. But, one interesting thing is that the correlation between different groups of commodity futures is very low, much lower than the correlation between different stock sectors (Erb and Harvey, 2006).

One important point to note here is the emerging country like India, commodity price has been increasing and highly volatile in the last couple of years. Very few studies are available on 
this issue and they don't clearly show the relationship between fundamental variables and commodity price. Therefore, this paper makes an attempt to study on this.

\section{Sample Size and Data Sources}

The impact of macroeconomic variables on individual commodity price cannot be observed due to its negligible effects and it cannot be justified. Therefore, to know the effects of macroeconomic variables on commodity prices, we have constructed commodity price indexes, which are the combination of different groups of commodities like agricultural, metals and energy commodities in India. Though, there are various commodities, consumed by consumers but it's very difficult to analyse all commodities. Therefore, in this study, we have selected few commodities from the basket of commodities and these are categorized broadly into three - (a) agricultural, (b) metals and (c) energy. These commodities are selected based on their demands. We have collected the wholesale index price of cereals, sugar, edible oil, cotton, rubber \& plastic products, aluminium, metal products, other non-ferrous metals, coal and mineral oil prices. All these commodities are categorized into three groups - food or agricultural (cereals, sugar, edible oil, cotton and rubber \& plastic products), metal (aluminium, metal products and other nonferrous metals) and energy (coal and mineral oil price). These commodities sub-index prices are collected from the Reserve Bank of India (RBI) and then have constructed the final commodity index for the study. Except for commodities wholesale sub-index prices, we have also collected the monthly exchange rate (Indian currency with US dollar), interest rate and demand. There are different interest rates, this study have used the 3-months Treasury Bill rate as a substitute for the interest rate. Similarly, there are no data particularly as demand, we have used the index of industrial production (IIP) as a proxy for demand. All these variables are collected from the Reserve Bank of India (RBI) database from January 2001 to June 2012. Though the commodities wholesale index prices in RBI are available in two different base periods, i.e., 1993-94 and 200405, we have converted the wholesale price sub-indexes for the base year 1993-94 to 2004-05 base year. Similarly, the IIP data are in two base years (i.e., 1993-94 and 2004-05) but we have converted to 2004-05 base year. All variables, except the T-bill rate, are converted into logarithmic values and are used for estimation purpose. So the study variables are all commodity 
price index (AC), metal price index (METAL), agricultural price index (AGRI), energy price index (ENERGY), TBill, exchange rate and IIP.

\section{Methodology of the Study.}

The relationships between selected study variables is examined by the autoregressive distributed lag model (ARDL) suggested by Pesaran et al. (2001). This method is adopted because of three reasons. Firstly, compared to other multivariate cointegration methods (i.e. Johansen and Juselius (1990), the bounds test is a simple technique because it allows the cointegration relationship to be estimated by OLS once the lag order of the model is identified. Secondly, adopting the bound testing approach means that pretest such as unit root is not required. That is the regressors can either I(0), purely I(1) or mutually cointegrated. Thirdly, the long-run and short run parameters of the models can be simultaneously estimated (Aregbeyen and Ibrahim (2012). We use variables in natural logarithm form to assess the significance of the relationship among the macroeconomic variables and the commodity prices. To investigate the relationship between these variables, the following ARDL model is applied.

The ARDL model involves estimating the conditional error correction version of the ARDL model for variables under estimation. The augmented ARDL ( $\left.\mathrm{p}, \mathrm{q}_{1}, \mathrm{q}_{2}, \ldots \ldots \ldots, \mathrm{q}_{\mathrm{k}}\right)$ is given by the following equation (Pesaran and Pesaran, 1997; Pesaran and Shin, 2001):

$\alpha(L, p) y_{t}=\alpha_{0}+\sum_{i=1}^{k} \beta_{i}\left(L, q_{i}\right) x_{i t}+\grave{\lambda} w_{t}+\varepsilon_{i} \quad \forall_{i}=1,2, \ldots, n$

Where, $\alpha(L, p)=1-\alpha_{1} L-\alpha_{2} L-\cdots-\alpha_{p} L^{p}$ and

$\beta_{i}\left(L, q_{i}\right)=\beta_{i 0}+\beta_{i 1} L+\beta_{i 2} L^{2}+\cdots+\beta_{i q_{i}} L^{q_{i}} \quad \forall_{i}=1,2, \ldots \ldots k$

Where $y_{t}$ is the dependent variable, $\alpha_{0}$ is the constant term, $\mathrm{L}$ is the lag operator, such that $L y_{t}=y_{t}-1, w_{t}$ is $\mathrm{s} \times 1$ vector of deterministic variables such as intercept term, time trends, or exogenous variables with fixed lags. The long-run elasticities are estimated by:

$\widehat{\phi}_{i}=\frac{\widehat{\beta}_{i}\left(1, \hat{q}_{i}\right)}{\phi(1, \hat{p})}=\frac{\widehat{\beta}_{i 0}+\widehat{\beta}_{i 1}+\cdots+\widehat{\beta}_{i \varphi}}{1-\widehat{\alpha}_{1}-\widehat{\alpha}_{2}-\cdots-\widehat{\alpha} \widehat{\phi}_{\hat{p}}} \quad \forall_{i}=1,2, \ldots \ldots, k$ 
Where, $\hat{p}$ and $\hat{q}_{i}, \mathrm{i}=1,2, \ldots ., \mathrm{k}$ are the selected (estimated) values of $\hat{p}$ and $\hat{p}_{i}, \mathrm{i}=1,2, \ldots, \mathrm{k}$. the long-run coefficients associated with the deterministic/exogenous variable with fixed lags are estimated by

$\pi=\frac{\widehat{\lambda}\left(\hat{p}, \hat{q}_{1}, \hat{q}_{2}, \ldots . . \hat{q}_{k}\right)}{1-\widehat{\alpha}_{1}-\widehat{\alpha}_{2}-\cdots-\widehat{\alpha}_{\hat{p}}}$

Where $\hat{\lambda}\left(\hat{p}, \hat{q}_{1}, \hat{q}_{2}, \ldots . \hat{q}_{k}\right)$ denotes the OLS estimates of $\lambda$ for the selected ARDL model.

The ARDL approach involves two steps for estimating the long-run relationship (Pesaran et al., 2001). The first step is to investigate the existence of a long-run relationship among all variables in the equation under estimation. The ARDL model estimaters $(p+1)^{k}$ number of regressions in order to obtain the optimal lag length for each variable, where $\mathrm{p}$ is the maximum number of lags to be used and $\mathrm{k}$ is the number of variables in the equation. The second step is to estimate the long-run relationship and short-run bidirectional causality between running variables. We run second step only if we found a long-run relationship in the first step (Narayan, 2004). This study uses a more general formula of the ECM with an unrestricted intercept and unrestricted trends (Pesaran et al., 2001):

$\Delta y_{t}=c_{0}+c_{1} t+\pi_{y y} y_{y-1}+\pi_{y x . x}+\sum_{i=1}^{p-1} \grave{\psi}_{i} \Delta z_{t-1}+\grave{w} \Delta X_{t}+\mu_{t}$

Where $c_{0} \neq 0$ and $c_{1} \neq 0$. The Wald test (F-statistics) for the null hypothesis is

$H_{0}^{\pi_{y y}}: \pi_{y y}=0, H_{0}^{\pi_{y x . x}}: \pi_{y x . x}=\grave{0}$, and alternative hypothesis

$H_{1}^{\pi_{y y}}: \pi_{y y} \neq 0, H_{1}^{\pi_{y x . x}}: \pi_{y x . x} \neq 0$. Hence, the joint null hypothesis of the interest in the above equation is given by $H_{0}=H_{0}^{\pi_{y y}} \cap H_{0}^{\pi_{y x \cdot x}}$, and the alternative hypothesis correspondingly stated as $H_{0}=H_{1}^{\pi_{y y}} \cap H_{1}^{\pi_{y x \cdot x}}$.

The asymptotic distributions of the F-statistics are non-standard under the null hypothesis of no cointegration relationships between the examined variables, irrespective of whether the variables are purely I(0) or I(1), or mutually cointegrated. Pesaran and Pesaran (1997) provide two sets of asymptotic critical values. The first set assumes that all variables are I(0); while the second set assumes that all variables are I(1). Therefore, if we find the computed F-statistic is greater than upper bound critical value, then we should reject the null hypothesis of no cointegration and 
conclude that a steady state of equilibrium between the variables exists. If we computed Fstatistic is less than the lower bound critical value, then we could not reject the null of cointegration. If the computed F-statistic should fall within the lower and upper bound critical values, then the result would be inconclusive. The model can be selected using the lag length criteria of Schartz-Criteria (SBC) or Akaike information criteria (AIC).

Following the discussion of theoretical models and the ARDL technique, we employed the Pesaran et al., (2001) procedure to investigate the existence of a long-run relationship in the form of the unrestricted error correction model for each variable, as follows:

$\Delta \ln y_{i}=\alpha_{0}+\beta_{1} \ln y_{i, t-1}+\beta_{2} \ln E X_{t-1}+\beta_{3} \ln I I P_{t-1}+\beta_{4} \ln I N T_{t-1}+\sum_{i=1}^{k} \delta_{1 i} \Delta \ln y_{i, t-i}+$

$\sum_{i=1}^{k} \delta_{2 i} \Delta \ln E X_{t-i}+\sum_{i=1}^{k} \delta_{3 i} \Delta \operatorname{lnII} P_{t-i}+\sum_{i=1}^{k} \delta_{4 i} \Delta \ln I N T_{t-i}+\varepsilon_{t}$

Where, $y_{i}=$ food index price, energy index price, metal index price and all commodity index price. $\Delta=$ first differencing operator, $\mathrm{K}=$ lag length for the Unrestricted Error-Correction Model (UECM) and $\varepsilon=$ white noise disturbance error term

The first step in the ARDL model is to estimate equation-5 using the ordinary least square (OLS). The second is to trace the presence of cointegration. Once cointegration relationship is established, the next step is to estimate the long-run coefficients using the ARDL model and short-run dynamic parameters using the error correction model. The error correction model helps to capture the speed adjustment among the variables affecting commodity index prices and macroeconomic variables. The co-integrating long-run relationship was estimated using the specification below:

$\ln y_{i}=\alpha_{0}+\beta_{1} \ln y_{i, t-1}+\beta_{2} \ln E X_{t-1}+\beta_{3} \ln I I P_{t-1}+\beta_{4} \ln I N T_{t-1}+\varepsilon_{t}$

The short-run dynamic model is specified thus:

$$
\begin{aligned}
& \Delta \ln y_{i}=\alpha_{0}+\sum_{i=1}^{k} \delta_{1 i} \Delta \ln y_{i, t-i}+\sum_{i=1}^{k} \delta_{2 i} \Delta \ln E X_{t-i}+\sum_{i=1}^{k} \delta_{3 i} \Delta \ln I I P_{t-i}+ \\
& \sum_{i=1}^{k} \delta_{4 i} \Delta \operatorname{lnINT} T_{t-i}+\delta_{5} \varepsilon c t_{t-1}+\varepsilon_{t}
\end{aligned}
$$

Where, $\varepsilon c t_{t-1}=$ the error correction term lagged for one period and $\delta=$ the coefficient for measuring speed of adjustment in equation-5. 
To estimate the values of variables in estimation model, it needs to choose an appropriate lag length. Though, there are different lag length selection criteria such as the Final Predicted Error (FPE), Akaike Information Criteria (AIC), Schwartz Information Criteria (SIC) and HQ (Hendricks Quant) respectively. But we have adopted AIC and SIC to select maximum lag for the estimation models. But this is relaxed for Johansen cointegration test.

Before examining any linkage between variables, we proceed to check the stationarity of selected data series using the unit root test.

\section{Empirical Interpretations}

Before we proceed to estimate the ARDL bound test, we have tested the stationarity of the variables to determine their order of integration. The results of the unit root tests are reported in Table-1A and 1B. In these tables, we have reported the ADF test and PP test results for commodity indexes and also for macroeconomic variables. Table-1A and $1 \mathrm{~B}$ indicate that at the level and also for first difference values, the variables are I(0) and I(1). It is seen, except Tbill and IIP, al other variables are I(1) but these two are I(0). Hence, the orders of integration of the variables lend support to the use of the ARDL bounds test rather than one of the alternative cointegration tests.

Table 1A: Augmented Dickey Fuller Unit Root Test Results

\begin{tabular}{|l|c|c|c|c|}
\hline \multicolumn{4}{|c|}{ Intercept } & \multicolumn{2}{|c|}{ Intercept with Trend } \\
\hline Variable & Level & First Diff & Level & First Diff \\
\hline Agriculture & 0.16 & $-11.96^{*}$ & 0.16 & $-11.99^{*}$ \\
Energy & 0.22 & $-7.78^{*}$ & -2.64 & $-7.83^{*}$ \\
Metal & 0.69 & $-3.86^{*}$ & -1.57 & $-4.57^{*}$ \\
Tbill & $-11.71 *$ & $-9.80^{*}$ & $-11.69 *$ & $-9.76^{*}$ \\
IIP & -1.40 & $-3.38^{*}$ & -2.18 & $-4.47^{*}$ \\
Exchange Rate & -0.65 & $-10.15^{*}$ & -0.68 & $-10.27^{*}$ \\
\hline
\end{tabular}

Notes:a. Critical values for unit root test ( ADF \& PP) are: -3.49 and -4.10 (without trend) and $-4.04,-4.10$ (with trend) respectively at $1 \%$ level and $5 \%$ levels

b. * and ** denote significant at 5 percent and 1 percent respectively

Source: Author's estimations 
Table 1B: Phillips Perron Unit Root Test Results

\begin{tabular}{|l|c|c|c|c|}
\hline \multicolumn{4}{|c|}{ 2001M01-2012M12 } \\
\hline Variable & Level & First Diff & Level & First Diff \\
\hline Agriculture & 0.86 & $-12.76^{*}$ & -1.97 & $-13.81^{*}$ \\
Energy & 0.38 & $-7.87^{*}$ & -2.27 & $-7.84^{*}$ \\
Metal & 1.22 & $-5.81^{*}$ & -1.16 & $-6.23^{*}$ \\
Tbill & $-11.71^{*}$ & $-136.07^{*}$ & $-11.69^{*}$ & $-136.68^{*}$ \\
IIP & -1.00 & $-33.56^{*}$ & $-8.22^{*}$ & $-33.49^{*}$ \\
Exchange Rate & -0.94 & $-10.16^{*}$ & -0.86 & $-10.27^{*}$ \\
\hline
\end{tabular}

Notes and Source: Same as in Table 1a

According to Pesaran et al. (2001), the ARDL cointegration model estimation follows two steps procedure. Firstly, we have to find out the optimum lag length using the different criteria like Schwartz Bayesian Criteria (SBC) and Akaike Information Criteria (AIC). Secondly, we have to estimate the Wald bound test for cointegration. The AIC model suggests that 2 is the optimum lag for agricultural index price and 3 is the optimum lag for energy and metal index price.

We have estimated the Wald bound test for agriculture index price, energy index price and metal index price with the selected macroeconomic variables like Tbill, IIP and Exchange rate. The results of the Wald bound test for cointegration show that the calculated F-statistics are 7785.72, 3843.95 and 3251.57 respectively which are highly significant, led to we reject the null hypothesis and accept the alternative hypothesis, i.e. there is a cointegration relationship among the variables in this model. Having found a long-run relationships between commodity index prices and macroeconomic variables, we have applied the ARDL model to estimate the long-run and short-run elasticities (Pesaran et al., 2001 and Pesaran and Shin, 1999).

The long-run coefficients of the variables under investigation are shown in the Table-2. The Table-2 indicates the long-run coefficient estimates for three commodities index price. All the regression equations are based on the ARDL model selected by the AIC. The Table-2A shows that the long-run coefficients for the regressor, namely lagged agriculture, iip and exchange rate are all highly significant at 5\% significance levels. This result suggests that a long-run relationship exists between agriculture index price and iip, and between agriculture and exchange rate. But there is no co-integration relationship emerged between agriculture and tbill, i.e. short 
term interest rate. This result indicates that both demand (IIP) and exchange rate are two major factors for change in India's agriculture index price.

Table 2: Estimated Long-run Coefficients Using the ARDL Model

\begin{tabular}{|c|c|c|c|}
\hline \multicolumn{4}{|c|}{ A: Dependent Variable- Agriculture Index Price } \\
\hline Regressor & Coefficient & Standard Error & T-Ratio \\
\hline AGRICULTURE(-1) & $0.91 *$ & 0.03 & $30.67[.000]$ \\
\hline TBILL & -0.02 & 0.05 & $-0.37[.712]$ \\
\hline IIP & $0.06 * *$ & 0.02 & $3.19[.002]$ \\
\hline EX & $0.18 * *$ & 0.09 & 2.09[.039] \\
\hline $\mathrm{C}$ & -5.85 & 3.79 & $-1.54[.125]$ \\
\hline R-Squared & 0.99 & R-Bar-Squared & \multirow[t]{2}{*}{0.98} \\
\hline DW-statistic & 2.03 & & \\
\hline \multicolumn{4}{|c|}{ B: Dependent Variable- Energy Index Price } \\
\hline ENERGY(-1) & $1.37 *$ & 0.08 & $17.13[.000]$ \\
\hline ENERGY(-2) & $-0.40^{*}$ & 0.08 & $-4.92[.000]$ \\
\hline TBILL & 0 & 0.05 & $-0.03[.979]$ \\
\hline TBILL(-1) & $0.10 * *$ & 0.05 & $2.09[.039]$ \\
\hline TBILL(-2) & -0.08 & 0.05 & $-1.75[.082]$ \\
\hline IIP & $0.04 * *$ & 0.02 & $2.38[.019]$ \\
\hline EX & -0.07 & 0.07 & $-0.98[.327]$ \\
\hline $\mathrm{C}$ & 3.05 & 3.39 & $0.90[.370]$ \\
\hline R-Squared & 0.99 & \multirow[t]{2}{*}{ R-Bar-Squared } & \multirow[t]{2}{*}{0.99} \\
\hline DW-statistic & 2.08 & & \\
\hline \multicolumn{4}{|c|}{ C: Dependent Variable- Metal Index Price } \\
\hline METAL(-1) & $1.44 *$ & 0.09 & $16.93[.000]$ \\
\hline METAL(-2) & -0.21 & 0.15 & $-1.40[.165]$ \\
\hline METAL(-3) & $-0.24 * *$ & 0.09 & $-2.76[.007]$ \\
\hline TBILL & 0.01 & 0.03 & $0.29[.771]$ \\
\hline IIP & 0.01 & 0.01 & $1.68[.096]$ \\
\hline EX & 0.02 & 0.04 & $0.58[.562]$ \\
\hline $\mathrm{C}$ & -1.09 & 1.68 & $-0.65[.518]$ \\
\hline R-Squared & 1.00 & \multirow[t]{2}{*}{ R-Bar-Squared } & \multirow[t]{2}{*}{1.00} \\
\hline DW-statistic & 2.04 & & \\
\hline Source: Author's Estin & & & \\
\hline
\end{tabular}

The Table-2B indicates that the long-run coefficients for the regressor, namely lagged energy index prices, short-term interest rate (i.e. TBill) and IIP are all highly significant at 5\% significance levels. This result suggests that a long-run relationship exists between energy index price and Tbill, and between energy index price and IIP. But there is no cointegration 
relationship emerged between energy and exchange rate. This result indicates that both demand (IIP) and short-term interest rate are two major factors for change in India's energy index price.

The Table-2C shows that the long-run coefficients for the regressor, namely lag metal index prices, iip, tbil and exchange rate are insignificant. This result suggests that there is no long-run relationship exists between metal index price and the macroeconomic variables. But the change in metal index price is due to some other factors.

Table 3: Error Correction Model (ECM) Results for the ARDL Model

\begin{tabular}{|lccc|}
\hline A: Dependent Variable-Agriculture Index Price & & \\
\hline Regressor & Coefficient & Standard Error & T-Ratio[Prob] \\
dTBILL & -0.02 & 0.05 & $-0.37[.712]$ \\
dIIP & $0.06^{* *}$ & 0.02 & $3.19[.002]$ \\
dEX & $0.18^{* *}$ & 0.09 & $2.09[.039]$ \\
dC & -5.85 & 3.79 & $-1.54[.125]$ \\
ecm(-1) & $-0.09^{* *}$ & 0.03 & $-2.97[.004]$ \\
\hline B: Dependent Variable-Energy Index Price & & \\
\hline dENERGY1 & $0.38^{*}$ & 0.08 & $4.59[.000]$ \\
dTBILL & 0 & 0.05 & $-0.01[.993]$ \\
dIIP & $0.04^{* *}$ & 0.02 & $2.27[.025]$ \\
dEX & -0.08 & 0.07 & $-1.05[.294]$ \\
dC & 3.38 & 3.37 & $1.01[.318]$ \\
ecm(-1) & $-0.03^{* * *}$ & 0.02 & $-1.92[.058]$ \\
\hline C: Dependent Variable-Metal Index Price & & \\
\hline dMETAL1 & $0.45^{*}$ & 0.09 & $5.29[.000]$ \\
dMETAL2 & $0.24^{* *}$ & 0.09 & $2.76[.007]$ \\
dTBILL & 0.01 & 0.03 & $0.29[.771]$ \\
dIIP & 0.01 & 0.01 & $1.68[.096]$ \\
dEX & 0.02 & 0.04 & $0.58[.562]$ \\
dC & -1.09 & 1.68 & $-0.65[.518]$ \\
ecm(-1) & -0.01 & 0.01 & $-1.12[.263]$ \\
\hline Source:Aut & & \\
\hline
\end{tabular}

Source: Author's Estimation

Table-3 presents the estimated error correction model (ECM) of the selected ARDL model. In Table-3A, the dependent variable is agriculture index price, shows that the ECM coefficient is (-0.09) negative, as expected, and highly significant at the five percent level. The ECM represents the speed of adjustment of the agriculture index price to its long-run equilibrium. Moreover, the significance of the ECM confirms the existence of the stable long-run relationship and points to a long-run cointegration relationship between the significant regressor and the 
agriculture index price. In addition to their long-run cointegration relationship, this result also suggests that both the IIP and Exchange rate over the previous month had Granger-caused the agriculture index price.

In Table-3B, the dependent variable is energy index price, shows that the ECM coefficient is $(-0.03)$ negative and highly significant at the ten percent level. The significance of the ECM confirms the existence of the stable long-run relationship and points to a long-run cointegration relationship between the significant regressor and the energy index price. In addition to their long-run cointegration relationship, this result also suggests that both the energy lagged price and IIP over the previous month had Granger-caused the energy index price.

In Table-3C, the dependent variable is metal index price, shows that the ECM coefficient is $(-0.01)$ negative and not significant even at the ten percent level. It confirms that there is no stable long-run relationship, and points to no long-run cointegration relationship between the significant regressor and the metal index price. This result also suggests that there is no causality between metal index price and macroeconomic variables.

\section{Conclusion.}

This paper examines the relationship between commodities index prices and macroeconomic variables in India over the period of January 2001 to June 2012 using the time series techniques of ARDL model and ECM model. The ARDL test suggests that there is long-run cointegration between the agriculture index price and macroeconomic variables, and also between energy index price and macroeconomic variables. But, there is no long-run cointegration between metal index price and macroeconomic variables. The results also indicate that IIP and Exchange rate have positive and significant effects on agricultural index price. This implies that that IIP and Exchange rate are vital macroeconomic variables that influence the agricultural index price in the study period. Similarly, the aggregate demand (i.e. IIP) is the positive and significant effect on energy index price. This implies that that IIP is a vital macroeconomic variable that influences the energy index price in the study period. But, there is no such macroeconomic variable we found which have a significant effect on the metal index price. 


\section{References}

1. Aksoy, M.A. and Beghin, J.C. (ed). Global Agricultural Trade and Developing Countries. The World Bank, 2005.

2. Alexandratos, N. (2008). Food Price Surges: Possible Causes, Past Experience, and Longer Term Relevance. Population and Development Review, 34 (4): 663-697.

3. Andersen, T., T. Bollerslev, F. Diebold, and Vega, C. (2003). Micro Effects of Macro Announcements: Real-Time Price Discovery in Foreign Exchange. American Economic Review, 93 (1): 38-62.

4. Anderson, K. and Masters, W. (ed). Distortions to Agricultural Incentives in Africa. The World Bank, 2009.

5. Aregbeyen, O.O. and Ibrahim, T.M. (2012). The Causal Relationship between Government Spending and Revenue in an Oil-Dependent Economy: the Case of Nigeria. the IUP Journal of Public Finance, X (1), 6-21.

6. Barnhart, Scott W. (1989). The Effects of Macroeconomic Announcements on Commodity Prices. American Journal of Agricultural Economics, 71(2): 389-403.

7. Borensztein, E. and Reinhart, C.M. (1994). The Macroeconomic Determinants of Commodity Prices. IMF Staff Papers, 41: 236-258.

8. Byrne, J., G. Fazio, and Fiess, N. (2011). Primary Commodity Prices: Co-Movements, Common Factors and Fundamentals. World Bank Policy Research Working Paper, No. 5578.

9. Cai, J., Y. Cheung and Wong, M.C.S. (2001). What Moves the Gold Market?. Journal of Futures Markets, 21(3): 257-278.

10. Chambers, M. J. and Bailey, R.E. (1996). A Theory of Commodity Price Fluctuations. Journal of Political Economy, 104 (5): 924-957. 
11. Christie-David, Rohan, M. Chaudhry, and Koch, T.W. (2000). Do Macroeconomics News Releases Affect Gold and Silver Prices?. Journal of Economics and Business, 52 (1): 405-421.

12. Commodity Futures Trading Commission (CFTC) report (2008). Swap Dealers and Index Traders, Staff Report No- PR5542-08.

13. Durnbush, R. (1985). Policy and Performance links between LDC Debtors and Industrial Nations. Brookings Papers on Economic Activity, 2, 303-368.

14. Dwyer, A., Gardner, G. and Williams, T. (2011). Global Commodity Markets- Price Volatility and Financialization. Belletin. June Quarter.

15. Erb, C. and Harvey, C. (2006). The Strategic and Tactical Value of Commodity Futures. Financial Analysts Journal, 62(2): 69-97.

16. Fleming, M. J., \& Remolona, E. M. (1999a). Price Formation and Liquidity in the U.S. Treasury Market: The Response to Public Information. Journal of Finance, 54(5): 1901-1915.

17. Frankel, J.A. (2006). The Effects of Monetary Policy on Real Commodity Prices. NBER Working Paper, No. 12713.

18. Frankel, J.A. and Hardouvelis, G.A. (1985). Commodity Prices, Money Surprises and Fed Credibility. Journal of Money, Credit and Banking, 17(4): 425-438.

19. Gilbert, C. L. (1990). The Rational Expectations Hypothesis in Models of Primary Commodity Prices. World Bank, Policy, Research and External Affairs, Working Paper, No. 384.

20. Johnson, S. and Juselius, K. (1990). Maximum Likelihood Estimation and Inference on Cointegration- with Applications to the Demand for Money, Oxford Bulletin of Economics and Statistics, 52 (2), 169-210. 
21. Kabia, M.B. and Gil, M. (2000). Short- and Long-run Effects of Macroeconomic Variables on the Spanish Agricultural Sector. European Review of Agricultural Economics, 27 (23): 449-471.

22. Kaufmann, R.K. (2011). The Role of Market Fundamentals and Speculation in Recent Price Changes for Crude oil, Energy Policy, 39 (1), 105-115.

23. Kim, Suk J., Fariboz Moshirian, and Eliza Wu. (2011). Dynamic Stock Market Integration Driven by the European Monetary Union: An Empirical Analysis. Journal of Banking and Finance, 29 (10): 2475-2502.

24. Labys, W. C. and Maizels, A. (1990). Commodity Price Fluctuations and MacroEconomic Adjustments in the Developed Countries. WIDER Working Papers, No.88.

25. Lescaroux, F. (2009). On the Excess Co-movement of Commodity Prices - A Note about the Role of Fundamental Factors in Short-run Dynamics. Energy Policy, 37(10): 3906-3913.

26. Multi Commodity Exchange Year Book, 2011.

27. Nag, R.N. and Goswami, B. (2008). Macroeconomics of Commodity Price Fluctuations: A Structuralist Approach. Trade and Development Review, 1 (2): 49-74.

28. Narayan, P.K. (2004). Fiji's Tourism Demand: the ARDL Approach to Cointegration, Tourism Economics, 10 (2), 193-206.

29. OECD-FAO Agricultural Outlook 2008-2017.

30. Palaskas, T. and Varangis, P. (1991). Is There Excess Comovement of Primary Commodity Prices?: A Cointegration Test, World Bank Working Paper, No. 758.

31. Pesaran, M.H., Pesaran, B. (1997). Working with Microfit 4.0: Interactive Econometric Analysis. United Kingdom: Oxford University Press. 
32. Pesaran, M.H., Shin, Y., Smith, R.J. (2001). Bounds Testing Approaches to the Analysis of Level Relationships. Journal of Applied Econometrics, 16 (3), 289-326.

33. Tsay, R.S. (2010). Analysis of Financial Time Series. Wiley, Third Edition.

34. UNCTAD. (2009), Trade and Development Report, 2009

35. UNCTAD. (2009). The Growing Interdependence between Financial and Commodity Markets. Discussion Paper, No. 195.

36. UNCTAD. (2010). Recent Commodity Market Developments: Trends and Challenges. Geneva, TD/B/C.1/MEM.2/7.

37. UNCTAD. (2011). Price Formation in Financialized Commodity Markets: The Role of Information. United Nations, New York and Geneva.

38. UNCTAD Discussion Paper 197, March 2010.

39. Zahid, S., A. Qayyum and Shahid, W. (2007). Dynamics of Wheat Market Integration in Northern Punjab, Pakistan. The Pakistan Development Review, 46(4): 817-830.

40. Zanias, G.P. (1993). Testing for Integration in European Community Agricultural Product Markets. Journal of Agricultural Economics, 44(3): 418-427.

\section{Appendix}

\section{A.1: Construction of Commodity Price Index}

In this chapter, we have constructed a specific commodity price index to assess the impact of fundamental variables on commodity prices. While constructing the commodity price index, we

capture the relative importance of the commodity for India using the weight of the commodity in the WPI basket (base 2004-05). In Table-1, we have reported the commodity price weight in 
WPI (2004-05). The formation of commodity price index is followed by the Laspeyres price index. The Laspeyres' price index formula is given as below:

$$
L_{t}=\frac{\sum_{j=1}^{n} p_{j t} q_{j 0}}{\sum_{j=1}^{n} p_{j o} q_{j 0}} \times 100
$$

Where, the subscript " $\mathrm{j}_{0}$ " refers to the base month value for commodity $\mathrm{j}$, and, t refers to the current month. By using this formula, we have estimated four commodity indexes, viz., food index, metal index, energy index and all-commodity index.

The selected fundamental variables are 3-month T-bill rate, exchange rate and economic growth (IIP as a proxy variable) which captures the key links of commodity prices with interest rate, demand and exchange rate. For instance, the links with the exchange rate is affected by both demands for physical commodities and demands for index investment from investors. Similarly, the links with interest rate may reflect effects of economic fundamentals, as well as portfolio rebalancing of index investors (Tang and Xiong, 2010).

Table A.2: WPI Weights for the Base Year 2004-05 (India)

\begin{tabular}{|lcccc|}
\hline Commodity & WPI Weight & New Weight & Commodity Index & Weight \\
\hline Cereals & 3.37 & 11.94 & & \\
Sugar, khandari and gur & 2.09 & 7.40 & & \\
Edible oils & 3.04 & 10.78 & & \\
Cotton textile & 2.61 & 9.22 & & \\
Rubber \& plastic products & 2.99 & 10.58 & Food index & 49.9 \\
Mineral oils & 9.36 & 33.16 & & \\
Coal & 2.09 & 7.42 & Energy index & 40.6 \\
Aluminium & 0.49 & 1.73 & & \\
Other non-ferrous metal & 0.52 & 1.82 & & \\
Metal products & 1.68 & 5.95 & Metal index & 9.5 \\
\hline
\end{tabular}

Source: Author's calculations from RBI database 